\title{
Laboratory Observations of Reproduction in the Deep-Water Zoarcids Lycodes cortezianus and Lycodapus mandibularis (Teleostei: Zoarcidae) ${ }^{1}$
}

\author{
Lara A. Ferry-Graham, ${ }^{2,3}$ Feffrey C. Drazen, ${ }^{4}$ and Veronica Franklin ${ }^{5}$
}

\begin{abstract}
The first observations of reproduction and associated behaviors in captive bigfin eelpout, Lycodes cortezianus, and pallid eelpout, Lycodapus mandibularis, are reported here. One Lycodes cortezianus pair produced 13 transparent and negatively buoyant eggs that were approximately $6 \mathrm{~mm}$ in diameter. These were laid on a hydroid-covered rock. The development period was about 7 months, and the young that emerged were approximately $2 \mathrm{~cm}$ in total length. An additional captive pair also exhibited mating behavior as the male repeatedly nudged the female and the pair produced a burrow under a sponge; however the male died before any mating. Two gravid female Lycodapus mandibularis were captured and laid between 23 and 46 eggs that were about $4 \mathrm{~mm}$ in diameter. These were released on the sandy substrate after the females moved the sand about the tank, and the eggs were negatively buoyant. These eggs were all unfertilized. Additional burrowing behavior was observed from other captive individuals, but no eggs were subsequently produced. Taken together, our observations suggest that burrowing or use of other protective structures is a reproductive behavior of central importance to zoarcids. Contrary to some earlier hypotheses, even midwater species likely return to the sediment to burrow and/or deposit eggs. This behavior means that field data regarding reproduction in this family will continue to be difficult to obtain, and the contribution of further study in laboratory situations should not be underestimated.
\end{abstract}

Eelpouts (Family Zoarcidae) are a group of approximately 240 species of mostly deepsea fishes distributed throughout the world's oceans (Anderson and Fedorov 2004). Many species are encountered rarely, due to their tendency to inhabit the outer shelf and upper slope habitats (Anderson and Fedorov 2004),

\footnotetext{
${ }^{1}$ Manuscript accepted 15 February 2006.

2 Author for correspondence.

${ }^{3}$ California State University, Moss Landing Marine Laboratories, 8272 Moss Landing Road, Moss Landing, California 95039 (phone: 831-771-4497; e-mail: lfgraham@mlml.calstate.edu).

${ }^{4}$ Department of Oceanography, University of Hawai'i at Mānoa, MSB 606, 1000 Pope Road, Honolulu, Hawai'i 96822.

${ }^{5}$ Monterey Bay Aquarium, 886 Cannery Row, Monterey, California 93940.
}

Pacific Science (2007), vol. 61, no. 1:129-139

(C) 2007 by University of Hawai'i Press

All rights reserved but it is one of the most speciose families of fishes in the deep sea (Pearcy et al. 1982). The increasing number of trawl-based surveys is steadily adding to our knowledge of the family; indeed, the number of known zoarcid species has grown by 20 in the past decade (Anderson 1994, Anderson and Fedorov 2004). Several zoarcid species are numerically abundant within their habitats (Adams et al. 1995, Lauth 1999, 2000), and they are regularly observed in photographic surveys of the continental slopes and rises of the eastern North Pacific (Stein et al. 1992, Adams et al. 1995, Cailliet et al. 1999). Nevertheless, information on their reproductive biology is rather limited.

We do know that nearly all are oviparous, producing large eggs, often greater than $5 \mathrm{~mm}$ in diameter, and relatively few eggs, tens to a few hundred, per clutch (Andriashev 1964, Levings 1969, Nash 1986, Moller and Gravlund 2003). Large eggs, in general, afford a great deal of maternal investment. Zoarcid 
TABLE 1

Comparative Reproduction Information for Zoarcids Known Primarily from Direct Observation of Spawned Clutches or Hatchlings. Junior Synonyms Are Included for Some Names to Assist with the Pairing of Species with Relevant Literature (see Anderson and Fedorov 2004)

\begin{tabular}{|c|c|c|c|c|c|c|c|}
\hline Species & $\begin{array}{l}\text { Egg } \\
\text { Diameter } \\
(\mathrm{mm})\end{array}$ & $\begin{array}{l}\text { No. of } \\
\text { Eggs }\end{array}$ & $\begin{array}{l}\text { Nature } \\
\text { of Eggs }{ }^{a}\end{array}$ & $\begin{array}{l}\text { Mode of } \\
\text { Deposition/ } \\
\text { Care }^{a}\end{array}$ & $\begin{array}{l}\text { Spawning } \\
\text { Period }\end{array}$ & $\begin{array}{l}\text { Development } \\
\text { Time }\end{array}$ & Method of Data Collection \\
\hline Austrolycus depressiceps & $9.2-9.8$ & 465 & A & $\mathrm{H}$ (under rock), Gf & & & $\begin{array}{l}\text { Field observations; intertidal } \\
\text { species (Matallanas et al. 1990) }\end{array}$ \\
\hline Botbrocara (= Allolepis) bollandi & 9.2 & & & & & & $\begin{array}{l}\text { Field observations (Okiyama } \\
\text { 1982); shallow species }\end{array}$ \\
\hline Dadyanos insignis & 5.0 & $64-161$ & A & $\mathrm{B}, \mathrm{Gfm}$ & March-April & & $\begin{array}{l}\text { Field observations: intertidal/ } \\
\text { subtidal (Gosztonyi 1977) }\end{array}$ \\
\hline Iluocoetes elongatus & $5.0-5.5$ & $100-126$ & A & $\mathrm{B}, \mathrm{Gf}$ & Early March & $\sim 2$ months & $\begin{array}{l}\text { Abundant field observations: } \\
\text { shallow (Gosztonyi 1977) }\end{array}$ \\
\hline Gymnelus viridis & $4.5-4.8$ & $5-17$ & & & & & $\begin{array}{l}\text { Field observations; shallow (Rass } \\
1941)^{b}\end{array}$ \\
\hline Lycodes (= Aprodon) cortezianus & 6 & 13 & $\mathrm{~A}, \mathrm{~N}$ & $\mathrm{H}, \mathrm{S}$ & & 7 months & Laboratory observation (this study) \\
\hline Lycodes palearis & $6-7$ & & A & B & & & $\begin{array}{l}\text { Aquarium observations (Slipp and } \\
\text { Delacy 1952) }\end{array}$ \\
\hline Lycodes pallidus & $5-6$ & 60 & & & Fall? & & $\begin{array}{l}\text { Field observations; shallow (Rass } \\
\text { 1941, Andriashev 1986) }\end{array}$ \\
\hline Lycodes gracilis (= Lycodes vablii gracilis) & 4 & $27-48$ & & & & & $\begin{array}{l}\text { Field observations; shallow (Rass } \\
\text { 1941) }\end{array}$ \\
\hline Lycodes (= Lycodopsis) pacificus & 5 & $7-52$ & & $\mathrm{H}$ ?, G? & Fall-winter & & $\begin{array}{l}\text { Submarine observations }(\sim 300 \mathrm{~m}) \\
\text { of putatively mated pairs; } \\
\text { dissection (Levings 1969) }\end{array}$ \\
\hline Lycodapus mandibularis & 4 & $23-46 ; 60-70$ & $\mathrm{~A}, \mathrm{~N}$ & B, H?, G? & & & $\begin{array}{l}\text { Laboratory observation (this study; } \\
\text { G. van Dykhuizen, Monterey } \\
\text { Bay Aquarium, pers. comm.) }\end{array}$ \\
\hline Melanostigma pammelas & 2.0 & & $\mathrm{~N}$ & & & & $\begin{array}{l}\text { Laboratory testing of ripe eggs } \\
\text { freshly dissected (Robison and } \\
\text { Lancraft 1984) }\end{array}$ \\
\hline Melanostigma atlanticum & 4 & $36-56$ & & $\mathrm{H}, \mathrm{G}$ ? & Fall & & $\begin{array}{l}\text { Box core samples (Silverberg et al. } \\
\text { 1987) }\end{array}$ \\
\hline Phucocoetes latitans & 4.5 & $11-25$ & & $\mathrm{H}$ (under rocks), Gf & & & $\begin{array}{l}\text { Field observations; intertidal } \\
\text { (Gosztonyi 1977) }\end{array}$ \\
\hline Zoarces (= Macrozoarces) americanus & 5.9 & $1,400-4,200$ & $\mathrm{~A}, \mathrm{~N}$ & $\mathrm{H}, \mathrm{Gf}$ & Late fall & $\sim 3$ months & $\begin{array}{l}\text { Laboratory observation (Yao and } \\
\text { Crim 1995); field observations } \\
\text { (Olsen and Merriman 1946, } \\
\text { Keats et al. 1985); subtidal }\end{array}$ \\
\hline
\end{tabular}


5 months Laboratory observations (Koya et

al. 1995); field observation (Tokranov 2005); shallow

(Tokranov 2005); shallow

Andriashev 1964,

Voskoboinikova and Laius

2003); shallow

${ }^{a}$ Key: A, adhesive; B, benthic; G, guarded by female (f) or male (m); H, in burrow or holes; L, ovoviviparous, bears live young; N, negatively buoyant; S, within structure such as rocks, hydroids; shallow, occurring $\leq 100 \mathrm{~m}$.

${ }^{b}$ Note that Gosztonyi (1977), Rass (1941), as well as others cited in this table, reported on a number of other species. Data from dissection of field-caught individuals with mature eggs are not included because spawning may or may not be imminent and egg size may not be at its maximum. 
young hatch almost entirely without a larval stage (Anderson 1984, Matallanas et al. 1990, Methven and Brown 1991). The large egg size has led to speculation that they must be laid in the benthic habitat (Mead et al. 1964). Indeed, the larvae are almost never taken in sampling trawls of the midwater (Anderson 1984). Large eggs and well-developed hatchlings may be particularly important in cold and/or deep habitats so that hatchlings are more likely to survive through the onset of exogenous feeding (Marshall 1953). Several authors have further claimed that a low fecundity suggests parental care (Mead et al. 1964, Breder and Rosen 1966). A handful of direct observations of shallow-water species has confirmed that, in those species (e.g., Zoarces americanus; see also Table 1), burrows or other structures are used for housing the eggs, and these are often guarded (Gosztonyi 1977, Anderson 1984, Keats et al. 1985, Silverberg et al. 1987, Steimle et al. 1999). Viviparity has evolved in some species (i.e., $Z$. viviparus and Z. elongatus [Koya et al. 1995, Ojaveer and Jarv 2003, Tokranov 2005]). Internal fertilization has also evolved in at least one egg-laying species (i.e., Z. americanus [Yao and Crim 1995]).

The vast majority of this information has come from the shallow-water representatives of the family, which make up only a fraction of the group as a whole. This is because routine direct observation is typically only possible for species that inhabit the intertidal or that portion of the subtidal accessible via scuba. The increased availability of submersibles and remotely operated vehicles (ROVs) has brought us a little more information regarding deeper-dwelling species (see Levings 1969), but this relies on fairly opportunistic encounter within a vast habitat. The remainder of what is known regarding reproduction in this family comes from dissection of trawlcaught individuals. From these individuals egg size and fecundity can be determined, and if the sampling effort is sufficiently allocated, the size of mature eggs (ready to be spawned) can be inferred, along with seasonality of reproduction. However, measurements seemingly so straightforward cannot be interpreted without caution. Without directly observing release of the eggs, estimates of maximum egg size, or even brood size, can be grossly in error. It is never certain if a female captured was ready to release the eggs, and females may not release all the eggs in the ovary at partuition. This makes laboratory observation of such species invaluable.

In August 2001 a clutch of zoarcid eggs was removed from a display tank at the Monterey Bay Aquarium. This suggested the possibility of laboratory investigations and prompted further study of this and other deep-dwelling species held in captivity at nearby institutions (the Monterey Bay Aquarium Research Institute and the Moss Landing Marine Laboratories). Our goal was to gather basic information regarding the reproductive behaviors, modes, and frequency for these and other zoarcids. Here we provide the first observations of reproduction and associated behaviors in captive specimens of the lower-shelf-dwelling Lycodes cortezianus (Gilbert) and the bathyal Lycodapus mandibularis Gilbert. We summarize the current state of knowledge regarding reproduction in the Zoarcidae that can be inferred from direct observation. Using these two sources of information, we suggest that all species within this family likely rely on benthic habitat and associated structures to burrow and/or deposit eggs.

\section{MATERIALS AND METHODS}

\section{Lycodes cortezianus Capture and Observation Conditions}

The pair of Lycodes cortezianus that produced the clutch had been in captivity at the Monterey Bay Aquarium since 14 April 1998 and was placed on exhibit in March 1999. They and several other individuals were captured in Monterey Bay via two otter trawls at depths of 50 to $155 \mathrm{~m}$ (starting and ending positions were $36^{\circ} 48.087^{\prime} \mathrm{N}, 122^{\circ} 55.127^{\prime} \mathrm{W}$ to $36^{\circ}$ $48.181^{\prime} \mathrm{N}, 121^{\circ} 56.134^{\prime} \mathrm{W}$ and $36^{\circ} 50.940^{\prime}$ $\mathrm{N}, 121^{\circ} 53.192^{\prime} \mathrm{W}$ to $36^{\circ} 51.142^{\prime} \mathrm{N}, 121^{\circ}$ $53.627^{\prime} \mathrm{W}$, respectively). There were no conspecifics in the tank with them at the time the clutch was produced. The clutch, when laid, was promptly removed from the display tank 
and placed in an isolated chamber at $6 \pm 11^{\circ} \mathrm{C}$ for closer observation during development.

Lycodapus mandibularis Capture and

\section{Observation Conditions}

Specimens of Lycodapus mandibularis were captured during the first 2 weeks of June 2002 in the water column $(300-1,000 \mathrm{~m})$ in the axis of Monterey Canyon within Monterey Bay $\left(36^{\circ} 42.00^{\prime} \mathrm{N}, 122^{\circ} 02.00^{\prime} \mathrm{W}\right)$, using the Monterey Bay Aquarium Research Institute's ROV Ventana. Each specimen was vacuumed into a 5-liter acrylic tank and held until the ROV returned to the surface. Collection in this manner results in specimens in pristine condition compared with conventional trawl sampling. Each animal was transferred in its acrylic chamber to a refrigerated room and then transferred to the laboratory (within $6 \mathrm{hr}$ of first capture), where they were maintained in 80-liter aquariums in a dark refrigerated room $\left(5^{\circ} \mathrm{C}\right)$. All observations were carried out in this room using red light illumination. Animals were fed two to three times weekly with a variety of foods including live brine shrimp (Artemia), wildcaught krill, and thawed and minced fish. These animals were being kept for other experiments regarding energetics and digestive physiology. However, the regular feeding schedule permitted routine observation. Daily observations were made of the gravid females after their reproductive state was identified.

Total length of each individual was measured opportunistically and a linear regression fit to the resulting data to infer growth rate.

RESULTS

Lycodes cortezianus Eggs and Development of Young

There were 13 eggs in the clutch and they were deposited on a hydroid-covered rock in August 2001. The eggs were transparent and approximately $6 \mathrm{~mm}$ in diameter. They were negatively buoyant and adhesive.

All of the eggs hatched between 28 March and 2 April 2002. Emerging young were about $2 \mathrm{~cm}$ in total length (TL) (Figure 1). Each emerged with a large yolk sac. Survivorship was initially high, with only two larvae being lost, possibly due to abrasion with the chamber in which they were housed. The developing young continued to be housed in $6 \pm 1^{\circ} \mathrm{C}$ water and began consuming exogenous food after approximately 2 weeks. They were fed twice daily a diet of enriched Artemia nauplii, live-reared copepods, and wild-caught plankton. At approximately 3 months of age they were placed on exhibit at the Monterey Bay Aquarium and their growth rate tracked opportunistically by directly measuring the remaining individuals (Figure 2). The individuals that could be tracked the longest $(n=3)$ grew nearly $8 \mathrm{~cm}$ over the subsequent 400 days that they were followed. Mortalities that occurred could not be attributed to any specific cause but were likely the result of predation in the tank or similar events.

\section{Lycodes cortezianus Reproductive Behavior}

The following November (2002) putative mating behaviors were noted between another Lycodes cortezianus pair in a different display tank. The male was seen repeatedly nudging the female and dug a large burrow in the sediment beneath a live sponge. This behavior was observed at various times throughout the day (7 a.m. -5 p.m.) from 6 November 2002 until a few days before the male died on 15 February 2003. This male died before any mating or egg laying occurred. The young Lycodes cortezianus from the initial clutch were also observed digging burrows at various times but none in association with behaviors that might be attributed to mating.

In September 2003, upon closure of the exhibit at the Monterey Bay Aquarium, the three remaining Lycodes cortezianus from the aforementioned clutch were transferred to the Moss Landing Marine Laboratories, where they were placed in a large open tank with a fine-sand substrate for observation with hope that additional mating behaviors would be observed. No burrowing or egglaying behavior was noted during the subsequent 18 months that they were held before dying. 


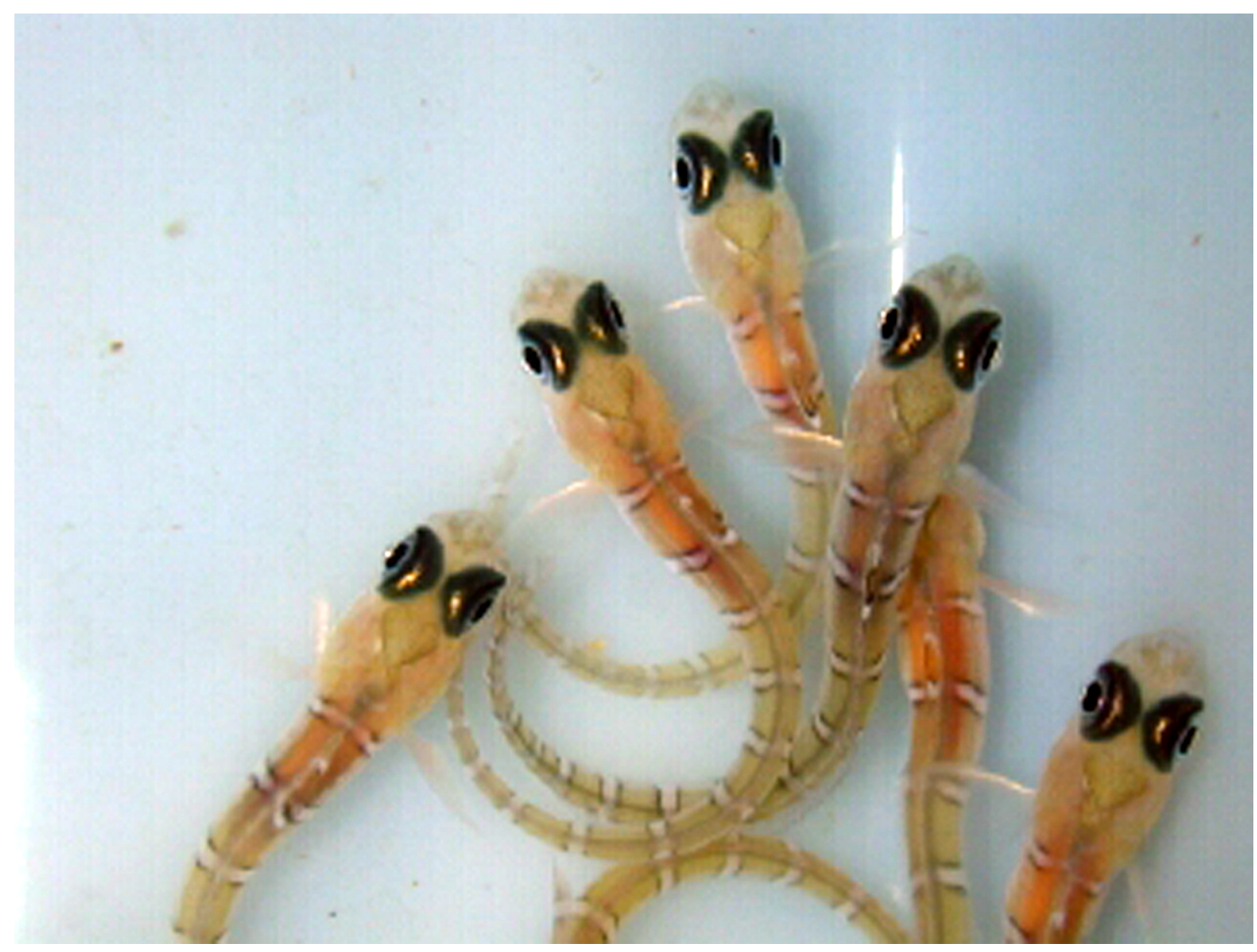

FIgURE 1. Photo of Lycodes cortezianus hatchlings, approximately $4 \mathrm{~cm}$ TL, taken 27 May 2002 at 51 days posthatching (by V.F.).

\section{Lycodapus mandibularis Eggs}

Two wild-caught females were apparently gravid when captured and laid eggs under direct observation in July and August 2002, respectively. Eggs were initially visible in the ovary, through the abdominal wall, between 21 and 51 days before being released. The abdomen became very distended over the period between this observation and the time of release. In both cases, the females were observed moving sand around the tank; possibly attempting to create burrows. The sand was too coarse for this and the second female was placed in a tank with a siltier substrate where she created small hollows before releasing the eggs.

The eggs were released by the females over a period of a few hours. They were ad- hesive and largely clustered together in pairs or triplets on the bottom (Figure 3). All eggs were transparent with a small nucleus in the center and several small oil droplets. Egg diameter was $4.1 \pm 0.2 \mathrm{~mm}$ (range, 4.1-4.4 $\mathrm{mm}$ ). Fecundity ranged from 23 to 46 for the two females. The eggs were apparently unfertilized in both cases. No additional egglaying behavior was observed over the subsequent $1.5 \mathrm{yr}$ (with new individuals being added periodically; total $n=7$ ).

Lycodapus mandibularis Reproductive Behavior

Burrowing activity was observed in the winter of 2004 and seemed to peak in January and February. The burrows were often tens of centimeters long and extended to the bottom 


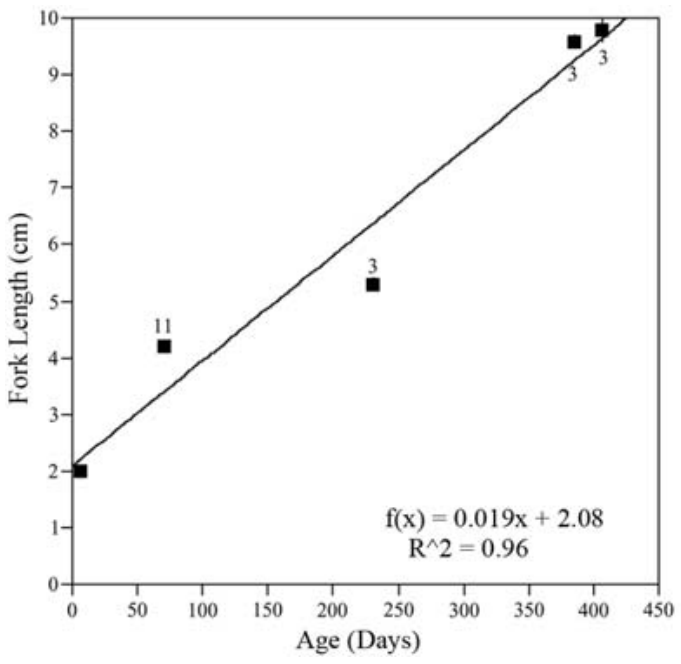

Figure 2. Growth rate of Lycodes cortezianus. Points are means \pm SE. The number of individuals alive at that date and contributing to that measurement is shown. A linear curve fit best to the data and the equation is provided along with the fit.

of the mud substrate ( $~ 7-8 \mathrm{~cm}$ deep) (Figure $3)$. Most were U-shaped, often at the edge of the tank but also at the edge of a rock placed in the mud months before. Burrows generally bent horizontally either right at the bottom of the tank or just a few centimeters below the surface and then extended for $10-20 \mathrm{~cm}$ before opening to the surface again. The burrows were approximately $1.5 \mathrm{~cm}$ in diameter-just a bit larger than the diameter of the eelpouts. It was impossible to trace all the burrows except for the openings and those that went along the side of the glass. Burrows did collapse, which often revealed branches of burrows not detectable before the cave-ins.

Digging was apparently performed mostly by one animal. This animal was recognizable because it was smaller $(\sim 12 \mathrm{~cm})$ than all but one of the other animals and it soon developed a red snout likely due to abrasion from digging. This animal was almost perpetually within a burrow, either visible within one or absent from the water column. Its digging behavior consisted of vigorous tail undulations that generated a jet of water and mud out of the back end of a burrow. Within a few days of the initial digging another slightly smaller individual was also seen to frequent the burrows but never developed an abraded snout and was never observed actually digging.

Unfortunately we never saw more than two individuals in the same burrow, nor did we observe gravid females during this interval. It was very curious that a midwater eelpout, Melanostigma pammelas, also housed in the tank (the only one) (Figure $3 D$ ) inhabited the burrows from the time of the first observations, occasionally resting next to the $L y c 0$ dapus mandibularis. This animal was not seen to dig and never developed abrasions, but it was nearly always in a burrow during that time. It did exit its burrow to feed several times but then returned very quickly.

\section{DISCUSSION}

Our observations here have highlighted several features of zoarcid reproduction previously unknown to biologists. For example, we noted that the Lycodes cortezianus eggs took 7 months to hatch. Although development time is strongly affected by temperature, that is still among the longest of any zoarcid species for which comparable data have been recorded (Table 1). The eggs were large, as is consistent with direct observations of individuals of other Lycodes species (egg diameters 5.0 to $7.0 \mathrm{~mm}$ [Table 1]) and with dissection of trawl-caught individuals (egg diameters 4.0 to $>8.0 \mathrm{~mm}$ [Moller and Jorgensen 2000]). However, there tended to be far more eggs in dissected Lycodes individuals, with values reported anywhere from the twenties (e.g., Lycodes sp. 1 [Moller and Jorgensen 2000]) to the thousands (Lycodes esmarkii [Andriashev 1986]). We noted that there are about 62 known species of Lycodes (Moller and Jorgensen 2000), and therefore such diversity may be expected. The eggs of Lycodes cortezianus were adhesive and negatively buoyant, suggesting they are deposited benthically as in Lycodes palearis (Slipp and Delacy 1952), the only other member of the genus for which such information is known. It is likely that they routinely utilize a protective structure as was observed in the aquarium setting used 


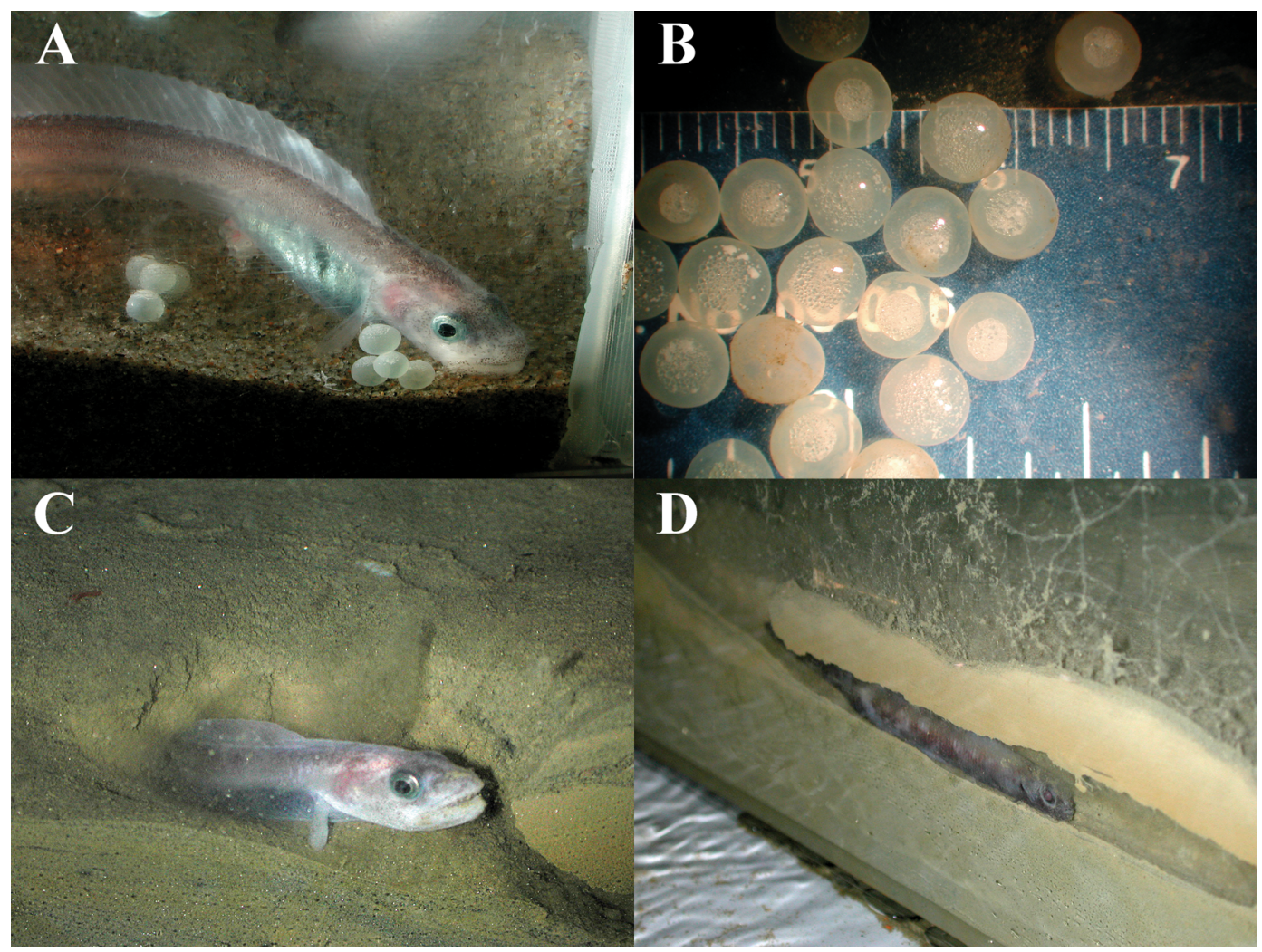

Figure 3. Photos of captive Lycodapus mandibularis (by J.C.D. and M. Gutowska). A, Female postspawning with several eggs in a small tank in the laboratory. B, Lycodapus mandibularis eggs; tick marks at the top of the ruler are millimeters. $C$, A different Lycodapus mandibularis in its burrow (approximately $12 \mathrm{~cm} \mathrm{TL}$ ); this is a site where the burrow caved in and the continuation of this burrow can be seen to the right. D, Melanostigma pammelas in a shallow burrow in the same tank as shown in $C$.

here. The clutch was small, and the emerging young well developed, like all other zoarcids (Anderson 1984). This is among the deepestdwelling zoarcid species for which these trends have been confirmed.

We also noted that Lycodapus mandibularis lay fewer and larger eggs than previously thought, and these are adhesive and negatively buoyant. These results are in stark contrast to Anderson (1981), in which it is suggested that Lycodapus mandibularis is completely pelagic and releases eggs directly into the water column. Anderson (1981) found maximum egg diameters of $1.7-1.9 \mathrm{~mm}$ and fecundities of $100 \pm 25$. We suggest that only a portion of the eggs in the ovary develop fully, thereby explaining the difference between Anderson's (1981) fecundity estimates and our own. Anderson's (1981) midwater trawl sampling had very good temporal coverage over a 2-yr period, yet he apparently never captured females with fully developed eggs. As we noted earlier, when females carry these large eggs they are easily discernible through the body wall for several weeks before spawning. This condition is so obvious that gravid individuals should even be visible on ROV footage; however, none was detected in a thorough search of Monterey Bay Aquarium Research Institute's video archive, which encompasses over $14 \mathrm{yr}$ of extensive in situ observation of the Monterey Bay underwater 
realm. We suggest that Lycodapus mandibularis probably leaves the water column to spawn, making their collection in midwater trawls or surveys a rarity at best.

The tendency of both of these species to dig burrows suggests a central importance of these, and perhaps other benthic structures, for protection at some or all life history stages. As we gain more information, albeit rather circumstantial in some cases, we are beginning to find evidence that benthic structures are of particular importance in this family for depositing clutches of eggs (Table 1). It may be the case that this trait is shared among all zoarcids. As stated previously, most of the supporting evidence comes from shallower species. In very cold regions, such as Patagonia, several species of zoarcids are intertidal or shallow subtidal. Many of these species have been observed guarding egg masses under rocks or kelp holdfasts (Gosztonyi 1977). In the Atlantic, species such as the ocean pout, Zoarces americanus, come into shallow water to set egg masses under boulders, which are also apparently guarded (Keats et al. 1985, Steimle et al. 1999). For deep-dwelling species, laboratory observations, such as those included here, are important for gathering additional information regarding the role of burrows because direct observation in the wild is difficult and opportunistic at best.

Indeed, over the past several decades of deep-sea sampling, only two zoarcid egg masses have been recovered. A purplish egg mass was independently recovered in a sediment sample from the Northeast Pacific and its identity tentatively assigned to the twolined eelpout, Botbrocara brunneum (Kendall et al. 1983). There were 26 eggs, each about $7 \mathrm{~mm}$ in diameter, in the complete, 20-dayold clutch (as determined by isotopic analysis), which was located about 10 to $12 \mathrm{~cm}$ below the sediment surface. The observed egg size is consistent with data collected via dissection of trawl-caught individuals of the same species (Ferry 1994; see also Okiyama [1982], who reported egg sizes of $9 \mathrm{~mm}$ for $B$. hollandi), and this lends tentative support to the notion that burrows are also used for reproduction in deeper-dwelling species.
This is, perhaps, not terribly surprising for groups such as Bothrocara that are benthic in nature. However, sediment sampling has also recovered eggs for the mesopelagic eelpout Melanostigma atlanticum. These eggs were collected together with the parents, and therefore identification was certain. This observation refuted the notion that all mesopelagic eelpouts spawn pelagically (Anderson 1984). Melanostigma atlanticum too used the benthic habitat for reproduction, depositing the egg mass in a burrow that may have been subsequently guarded (Silverberg et al. 1987).

The box core collection of Melanostigma atlanticum and our laboratory observations of Lycodapus mandibularis together suggest a benthic mode of reproduction for mesopelagic eelpouts, as for other zoarcids (Table 1). Previous studies of Lycodapus mandibularis failed to detect this because the benthic habitat was not sampled. Our hypothesis is supported by the observation that females with large eggs were also never collected in the mesopelagic realm. If we are correct, the benthic egglaying habit would be conserved within all members of the zoarcid family. Their behavior, possibly a phylogenetic constraint, may explain why these organisms are part of the nearshore/canyon community and are only occasionally taken far offshore. Additional laboratory studies are warranted to further evaluate our supposition that burrows and other benthic structures are of central importance to zoarcid reproduction, and to more generally determine the reproductive habits of this family of fishes.

\section{ACKNOWLEDGMENTS}

We thank M. Gutowska for assisting in the husbandry of the Lycodapus mandibularis. B. Robison of Monterey Bay Aquarium Research Institute kindly provided ROV dive time for Lycodapus mandibularis collections. G. Cailliet of Moss Landing Marine Laboratories facilitated the collection of Lycodes cortezianus. S. Lisin of Monterey Bay Aquarium assisted with retrieval of collection and husbandry information. We thank the captain and crews of the R/V Pt. Sur and R/V Pt. Lobos, who facilitated the deployment of the 
otter trawls and the ROV Ventana, respectively. Helpful feedback on the manuscript was provided by G. Cailliet and D. Ebert. J.C.D. was supported by a Monterey Bay Aquarium Research Institute postdoctoral fellowship, L.F.G. by a Visiting Scientist position at Moss Landing Marine Laboratories.

\section{Literature Cited}

Adams, P. B., J. L. Butler, C. H. Baxter, T. E. Laidig, K. A. Dahlin, and W. W. Wakefield. 1995. Population estimates of Pacific coast groundfishes from video transects and swept-area trawls. Fish. Bull. 93:446455.

Anderson, M. E. 1981. Aspects of the natural history of the midwater fish Lycodapus mandibularis (Zoarcidae) in Monterey Bay, California. Pac. Sci. 34:181-194.

- 1984. Zoarcidae: Development and relationships. Pages 578-582 in H. G. Moser, ed. Ontogeny and systematics of fishes. American Society of Ichthyologists and Herpetologists Special Publication No. 1.

- 1994. Systematics and osteology of the Zoarcidae (Teleostei: Perciformes). J. L. B. Smith Inst. Ichthyol. Bull. 60:1120.

Anderson, M. E., and V. V. Fedorov. 2004. Family Zoarcidae Swainson 1839Eelpouts. California Academy of Sciences Annotated Checklists of Fishes No. 34.

Andriashev, A. P. 1964. Fishes of the northern seas of the USSR. Izd. Akad. Nauk SSSR Moscow. Israel Program for Scientific Translations.

_ 1986. Zoarcidae. Pages 1130-1150 in P. J. P. Whitehead, M.-L. Bauchot, J.-C. Hureau, J. Nielsen, and E. Tortonese, eds. Fishes of the north-eastern Atlantic and the Mediterranean. Vol. 3. UNESCO, Paris.

Breeder, C. M., and D. E. Rosen. 1966. Modes of reproduction in fishes. American Museum of Natural History, New York.

Cailliet, G. M., A. H. Andrews, W. W. Wakefield, G. Moreno, and K. L. Rhodes. 1999. Fish faunal and habitat analyses using trawls, camera sleds and submersibles in benthic deep-sea habitats off central California. Oceanol. Acta 22:579-592.

Ferry, L. A. 1994. Aspects of the natural history of two-line eelpouts (Bothrocara brunneum, Family Zoarcidae). M.S. thesis, San Francisco State University and Moss Landing Marine Laboratories, Moss Landing, California.

Gosztonyi, A. E. 1977. Results of the research cruises of FRV Walther Herwig to South America. XLVIII. Revision of the South American Zoarcidae (Osteichthyes, Blennoidei) with the description of three new genera and five new species. Arch. Fischereiwiss. 27:191-249.

Keats, D. W., G. R. South, and D. H. Steele. 1985. Reproduction and egg guarding by Atlantic wolffish (Anarbichas lupus: Anarhichidae) and ocean pout (Macrozoarces americanus: Zoarcidae) in Newfoundland waters. Can. J. Zool. 63:2565-2568.

Kendall, A. W., Jr., C. D. Jennings, T. M. Beasley, R. Carpenter, and B. L. K. Somayajulu. 1983. Discovery of a cluster of unhatched fish eggs of a zoarcid buried 10 to $12 \mathrm{~cm}$ deep in continental slope sediments off Washington State. Mar. Biol. (Berl.) 75:193-199.

Koya, Y., T. Matsubara, T. Ikeuchi, N. Okubo, S. Adachi, and K. Yamauchi. 1995. Reproductive cycle and embryonic growth during gestation of the viviparous teleost, Zoarces elongatus. Page 237 in F. Goetz and P. Thomas, eds. 5th International Symposium on the Reproductive Physiology of Fish. University of Texas at Austin Marine Science Institute, Port Aransas.

Lauth, R. R. 1999. The 1997 Pacific west coast upper continental trawl survey of groundfish resources off Washington, Oregon, and California: Estimates of distribution, abundance, and length composition. NOAA Tech. Memo. NMFS-AFSC98.

2. 2000. The 1999 Pacific west coast upper continental trawl survey of groundfish resources off Washington, Oregon, and California: Estimates of distribution, abundance, and length composition. NOAA Tech. Memo. NMFS-AFSC115. 
Levings, C. D. 1969. The zoarcid Lycodopsis pacifica in outer Burrard Inlet, British Columbia. J. Fish. Res. Board Can. 26:24032412.

Marshall, N. B. 1953. Egg size in arctic, antarctic and deep-sea fishes. Evolution $7: 328-341$.

Matallanas, J., J. Rucabado, D. Lloris, and M. P. Olivar. 1990. Early stages of development and reproductive biology of the South-American eelpout Austrolycus depressiceps Regan, 1913 (Teleostei: Zoarcidae). Sci. Mar. 54:257-261.

Mead, G. W., E. Bertelsen, and D. M. Cohen. 1964. Reproduction among deep-sea fishes. Deep-Sea Res. 11:569-596.

Methven, D. A., and J. A. Brown. 1991. Time of hatching affects development, size, yolk, volume, and mortality of newly hatched Macrozoarces americanus (Pisces: Zoarcidae). Can. J. Zool. 69:2161-2167.

Moller, P. R., and P. Gravlund. 2003. Phylogeny of the eelpout genus Lycodes (Pisces Zoarcidae) as inferred from mitochondrial cytochrome $b$ and $12 \mathrm{~S}$ rDNA. Mol. Phylogenet. Evol. 26:369-388.

Moller, P. R., and O. A. Jorgensen. 2000. Distribution and abundance of eelpouts (Pisces, Zoarcidae) off West Greenland. Sarsia 85:23-48.

Nash, R. D. M. 1986. Aspects of the general biology of Vahl's eelpout, Lycodes vahlii gracilis M. Sars, 1867 (Pisces, Zoarcidae), in Oslofjorden, Norway. Sarsia 71:289296.

Ojaveer, H., and L. Jarv. 2003. Eelpout, Zoarces viviparus (L.). Pages 316-322 in E. Ojaveer, E. Pihu, and T. Saat, eds. Fishes of Estonia. Estonian Marine Institute, Tallinn.

Okiyama, M. 1982. Manuals for the larval fish taxonomy (9). Percoid larvae and spination. Oceans Mammals 4:92-99.

Olsen, Y. N., and D. Merriman. 1946. Studies of the marine resources of southern New England. IV. The biology and economic importance of the ocean pout, Mac- rozoarces americanus (Bloch and Schneider). Bull. Bingham Oceanogr. Collect. Yale Univ. 9:1-184.

Pearcy, W. G., D. L. Stein, and R. S. Carney. 1982. The deep-sea benthic fish fauna of the northeastern Pacific Ocean on Cascadia and Tufts Abyssal Plains and adjoining continental slopes. Biol. Oceanogr. 1:375427.

Rass, T. S. 1941. Analogous or parallel variations in structure and development of fishes in northern and arctic seas. Moscow Society of Naturalists, Jubilee Publication 1805-1940:1-60.

Robison, B. H., and T. M. Lancraft. 1984. An upward transport mechanism from the benthos. Naturwissenschaften 71:322-323.

Silverberg, N., H. M. Edenborn, G. Ouellet, and P. Beland. 1987. Direct evidence of a mesopelagic fish, Melanostigma atlanticum (Zoarcidae) spawning within bottom sediments. Environ. Biol. Fishes 20:195-202.

Slipp, J. W., and A. C. Delacy. 1952. On the distribution and habits of the wattled eelpout, Lycodespalearis. Copeia 1952:201-203.

Steimle, F. W., W. W. Morse, P. L. Berrien, D. L. Johnson, and C. A. Zetlin. 1999. Essential fish habitat source document: Ocean Pout, Macrozoarces americanus, life history and habitat characteristics. NOAA Tech. Memo. NMFS-NE-129.

Stein, D. L., B. N. Tissot, M. A. Hixon, and W. Barss. 1992. Fish-habitat associations on a deep reef at the edge of the Oregon continental shelf. Fish. Bull. 90:540-551.

Tokranov, A. M. 2005. Distribution and some biological characteristics of the eastern eelpout Zoarces elongatus (Zoarcidae) in Kamchatka waters of the Sea of Okhotsk. Vopr. Ikhtiol. 45:62-69.

Voskoboinikova, O. S., and D. L. Laius. 2003. Osteological development of European eelpout Zoarces viviparus (Zoarcidae). Vopr. Ikhtiol. 43:671-685.

Yao, Z., and L. W. Crim. 1995. Copulation, spawning and parental care in captive ocean pout. J. Fish Biol. 47:171-173. 
